Bioprospects of Coastal Eubacteria 
Sunita Borkar

Editor

\section{Bioprospects of Coastal Eubacteria}

Ecosystems of Goa

睹 Springer 


\section{Editor}

Sunita Borkar

Associate Professor and Head

Department of Microbiology

P.E.S.s S.R.S.N. College of Arts

and Science

Ponda

Goa

India

ISBN 978-3-319-12909-9

ISBN 978-3-319-12910-5 (eBook)

DOI 10.1007/978-3-319-12910-5

Library of Congress Control Number: 2015931381

Springer Cham Heidelberg New York Dordrecht London

(C) Springer International Publishing Switzerland 2015

This work is subject to copyright. All rights are reserved by the Publisher, whether the whole or part of the material is concerned, specifically the rights of translation, reprinting, reuse of illustrations, recitation, broadcasting, reproduction on microfilms or in any other physical way, and transmission or information storage and retrieval, electronic adaptation, computer software, or by similar or dissimilar methodology now known or hereafter developed.

The use of general descriptive names, registered names, trademarks, service marks, etc. in this publication does not imply, even in the absence of a specific statement, that such names are exempt from the relevant protective laws and regulations and therefore free for general use.

The publisher, the authors and the editors are safe to assume that the advice and information in this book are believed to be true and accurate at the date of publication. Neither the publisher nor the authors or the editors give a warranty, express or implied, with respect to the material contained herein or for any errors or omissions that may have been made.

Printed on acid-free paper

Springer is part of Springer Science+Business Media (www.springer.com) 
To Our Mentor Prof. Saroj Bhosle 


\section{Foreword}

Microorganisms have been shown to be the most versatile living organisms on Earth due to their multifunctional abilities. The promise of these organisms as biological resources was recognized by the discoverer of these organisms, Antonie Philips van Leeuwenhock, often called "The Father of Microbiology". Eubacteria, an important group of microorganisms, embodies diverse organisms that colonize and survive in a variety of habitats in natural environment, and are an important source of primary and secondary metabolites that are valuable to many industries. These organisms also play an important role in recycling of organic matter, biodegradation, bioremediation, waste management, and many other applications.

India's terrestrial, marine, and other aquatic ecosystems offer high diversity of biological forms. Goa, a tiny state on the central west coast of India, with an area of $3702 \mathrm{sq} . \mathrm{km}$, harbors many coastal and estuarine ecosystems, including low-nutrient sand dunes, nutrient-rich mangroves, beaches, rivers, etc. These ecosystems support an impressively diverse array of microorganisms.

Professor Saroj Bhosle, who joined the Goa University as a faculty in the 1980s, focused her research career at the university on Eubacteria found in the upper ecosystems. Her research on isolation, characterization, and industrial applications of the Eubacteria made her laboratory into an important center of learning in this field in India. The 15 doctoral students whose research was supervised by her with commitment, dedication, and innovation are now experts in various fields associated with Eubacteria by their own right. This book "Bioprospects of Coastal Eubacteria" brings together their expertise to provide new and useful insights into the working of coastal ecosystems of Goa. I compliment and congratulate Dr. Sunita Borkar for her notable venture in compilation of various research articles as chapters in the book.

I am sure that the book, which is being published as Dr. Bhosle steps down from her position as Professor in the Department of Microbiology at Goa University on superannuation, will benefit graduates, postgraduates, and researchers interested in 
the field of microbiology of coastal ecosystems. I wish Dr. Bhosle all the best as she takes on new challenges after retirement from the university.

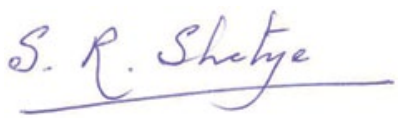

Dr. Satish Ramnath Shetye Vice Chancellor

Goa University 


\section{Preface}

Microbiology is an inherently valuable, fascinating branch and useful discipline of biological sciences with its own orientation and emphasis that offers an intimate view of an invisible world.

Microorganisms have promising potential in different fields as reflected in their diversity and unique characteristics. The role of microbes in the generation of biological resources is immense and has been well appreciated. The observation made by the renowned microbiologist, Louis Pasteur, about 160 years ago that "Life would not remain possible in the absence of microbes" has proved "The role of infinitely small as infinitely large". Not only natural products of microbial origin known earlier are better understood now but also newer ones are being added to the list. Their multifarious applications in all aspects of human life and environment are of immense importance.

Among several microorganisms, Eubacteria plays a very important role in our lives in recycling of organic matter, biodegradation, bioremediation and waste management and have tremendous potential in biodiscovery, soil fertility, crop protection, nutrition, etc. Pathogens are of concern to human health as they can cause fatalities. But, despite their recognized importance less than $5 \%$ of the world's Eubacteria are on record, and their meaningful exploitation is possible only if the perspectives of the cultures are properly documented with readily accessible information.

India is immensely rich in its diversity of biological forms, which includes all living organisms from ecological niches like terrestrial, marine, and other aquatic ecosystems. These niches provide natural enrichment for an impressively large array of microorganisms, and are an important repository having unique microbial flora suitable to their unique and highly variable environment. However, as stated by Edward Wilson, "Biodiversity is the earth's most important but least utilized resource".

Coastal zones of Goa have been exclusively used for agriculture, shell fishing, and traditional fishing and need to be explored for isolation and characterization of Eubacteria. Broad-based studies of characterization and the promising potential of Eubacteria from coastal econiches of Goa have been investigated and explored in research laboratory under the able guidance of reputed microbiologists of India, 
Prof. Saroj Bhosle, Goa University, Taleigao Plateau, Goa. She has been working in this field for more than three decades with commitment, dedication, and innovative approach.

I strongly believe that the research we plan and perform must yield results that are of global significance in relevance and applicability. For this purpose, I requested my co-researchers to contribute articles for this book. "Bioprospects of Coastal Eubacteria" therefore, is an attempt to survey and consolidate the research on the potentials of Eubacteria mostly isolated from coastal ecosystems of Goa on varied microbiological aspects. It is not intended to be an exhaustive catalog of everything that has been done. Rather, it is an attempt to give the reader an overview of potentials of Eubacteria and an insight into research that can be oriented in different fields of applications in microbiology and biotechnology.

The chapters put together in this book, written by experts in their own field, will hopefully provide useful insights on ecology and applied aspects of Eubacteria from diverse coastal ecosystems of Goa and open new avenues of research for scientific communities. Written in a lucid language and illustrative manner for easy understanding, this book will benefit graduates, postgraduates, and researchers interested in the field of microbiology and scientists working at different levels and disciplines. 


\section{Acknowledgements}

It gives me immense pleasure to express my deep sense of gratitude to my mentor, Professor Saroj Bhosle, for her invaluable guidance, stimulating discussion, and constant inspiration during the progressive development of this endeavor. She has been a rich source of suggestions about content, order, depth, organization, and readability. I, as an editor, and we, as authors, have been fortunate to have an exceptional guide who meets every challenge with patience, positive disposition, insight, and professionalism. Her expertise as a microbiologist has proved authenticity with this worthy contribution.

I gratefully acknowledge the scholarly contributions of my fellow researchers to the world of microorganisms who have added highly informative chapters to this book. I am indebted to them for their time and patience during the process of rigorous edition. Thank you for being so accommodating and prompt.

I place on record my deep sense of gratitude to The President Shri Ravi S. Naik, the management members and the Principal, Dr. Anil Dinge of P. E. S's S. R. S. N. College of Arts and Science, Farmagudi, Ponda, Goa. I am indebted to the Department of Higher Education, Government of Goa, for relieving me of my regular duties to take up this endeavor. I am grateful to the Vice Chancellor, Goa University, for writing the foreword to this book.

I thank Dr. Nimali Prabhu, Dr. Maria Celisa Santimano, Dr. Trelita DeSouza, Dr. Rasika Gaokar, Dr. Teja Gaonkar, Dr. Naveen Krishnamurthy, Dr. Rupali Bhagat, Ms Neha Prabhu and Prof. Sushanta Basu, in preparing the manuscript for publication and everyone who directly or indirectly contributed to bring out this book.

I am indeed indebted to my family for their unconditional support and cooperation during the innumerable hours taken from them to carry out this work. Thank you for caring about me.

Special thanks are due to the production staff of Springer, Netherlands, especially, Juliana Pitanguy, Mariëlle Klijn, and Megha Koirala for their timely suggestions and for shouldering the responsibility of printing and publishing.

I think that readers' satisfaction is the best reward for the editor, contributing authors, and the publisher.

Sunita Borkar 


\section{Contents}

1 Coastal Sand Dunes: A Potential Goldmine of Bioresources

Aureen L. Godinho

2 Eubacterial Siderophores and Factors Modulating Their Production

Teja Gaonkar

3 Denitrifying Bacteria: Physiological Response to Hydrocarbons

Trelita de Sousa

4 Alkaliphilic Bacteria: Diversity, Physiology and Industrial Applications

Sunita Borkar

5 Biodegradation of Aromatic Compounds by Alkaliphilic Bacteria ....

Rasika Desai Gaokar

6 Response of Alkaliphilic Bacteria to Aromatic Amines

Naveen Kumar Krishnamurthy

7 Insights into Organic-Solvent-Tolerant Bacteria and Their Biotechnological Potentials

Yogita N. Sardessai

8 Heterotrophic Bacteria Producing Polyhydroxyalkanoates:

A Biodegradable Polymer

Nimali N. Prabhu

9 Bacterial Synthesis of Polyhydroxyalkanoates Using

Renewable Resources

Maria Celisa Santimano 
10 Transformation of Triphenyltin by Eubacteria: Fate and Effects in Environmental System .

Sangeeta Jadhav

11 Bacteria Adhered to Particulate Matter and Their Role in Plant Litter Mineralization

Amrita Kharangate-Lad

12 Feruloyl Esterase: A Principal Biodegradative Enzyme Cristabell Pinto

13 Bio-processing of Coir-A Natural Fibre for Diversified End Use .... 225 Anita Das Ravindranath

14 Role of Microbes in Vermicomposting: A Review 241 Prakash Mallappa Munnoli

15 Prevalence of Listeria in Milk from Farm to Table 263 Dilecta D'Costa

Index 289 


\section{About the Editor}

Dr. Sunita Borkar Associate Professor and Head, Department of Microbiology, P. E. S. S. R. S. N. College of Arts and Science, Farmagudi, Ponda, Goa, started with the Department of Microbiology at the same college in 1989 as Lecturer after an MSc from Bombay University and became Associate Professor in 2006. She obtained her Doctoral degree in 2003 during her teaching tenure from Goa University. She worked on "Studies on Alkaliphiles-An Industrially Significant Group of Extremophiles" under the able guidance of Professor Saroj Bhosle. She has 27 years of teaching and research experience, and has guided project work of 40 undergraduate students, two PhD scholars as a coguide, and one MPhil student. She has to her credit three minor research projects funded by UGC and one major research project funded by the Ministry of Earth Sciences, Goverment of India, New Delhi. Her major research interests encompass diversity of alkaliphilic bacteria, bioremediation, phosphate solubilization, and PGPR. Dr. Borkar has participated and presented several research papers at national and international conferences and symposia, and published research papers and articles related to her research interest. She is a life member of "Association of Microbiologists of India" and has received Carmelite Award for the best outgoing graduate student.

Microbiology P.E.S.s S.R.S.N. College of Arts And Science, Ponda, Goa, India 


\section{Contributors}

Sunita Borkar Department of Microbiology, P.E.S's Shri Ravi Sitaram Naik College of Arts \& Science, Ponda, Goa, India

Dilecta D'Costa Government College of Arts, Science \& Commerce, Marcela, Goa, India

Trelita de Sousa Department of Microbiology, Goa University, Taleigao Plateau, Goa, India

Rasika Desai Gaokar Department of Microbiology, PES's Shri Ravi Sitaram Naik College of Arts and Science, Ponda, Goa, India

Teja Gaonkar Department of Microbiology, Goa University, Taleigao Plateau, Goa, India

Aureen L. Godinho Department of Microbiology, Goa University, Taleigao Plateau, Goa, India

Sangeeta Jadhav CSIR-National Institute of Oceanography, Dona Paula, Goa, India

Amrita Kharangate-Lad Department of Microbiology, Goa University, Taleigao Plateau, Goa, India

Naveen Kumar Krishnamurthy Fomento Resources, Panjim, Goa, India

Prakash Mallappa Munnoli S D M College of Engineering and Technology, Dhavalagiri, Dharwad, India

Cristabell Pinto Department of Microbiology, Goa University, Taleigao Plateau, Goa, India

Nimali N. Prabhu Department of Biological Sciences, Birla Institute of Technology and Science-Pilani, Zuarinagar, Goa, India

Anita Das Ravindranath Coir Board, Central Coir Research Institute, Alleppey, Kerala, India

Maria Celisa Santimano Department of Biological Sciences, Birla Institute of Technology and Science-Pilani, Zuarinagar, Goa, India

Yogita N. Sardessai Goa College of Pharmacy, Panaji, Goa, India 